\title{
Интеграция локальных геоботанических баз данных и глобальных информационных систем для поддержки сравнительных ландшафтоведческих исследований
}

\author{
Nizamatdin Mamutov ${ }^{1}$ \\ ${ }^{1}$ Affiliation not available
}

May 5, 2020

УДК 502.3 (575.1)

Н.К.Мамутов, П.Р.Реймов, С.Ж.Абдиреймов, Я.Г.Худайбергенов, В.А.Статов

Каракалпакский государственный университет, Нукус, Узбекистан

Аннотация.

В статье обсуждается интеграция локальных геоботанических баз данных и глобальных информационных систем для поддержки сравнительных исследований ландшафта с использованием Южного Аральского моря и Северного Каспия. В статье также исследуются изменения ландшафта в условиях антропогенных факторов с использованием ГИС технологий и дистанционного зондирования.

Салыстырмалы ландшафттық зерттеулерді қолдау үшін жергілікті геоботаникалық мәліметтер базасы мен ғаламдық ақпараттық жүйелерді біріктіру

Н.К.Мамутов, П.Р.Реймов, С.Ж.Абдиреймов, Я.Г.Худайбергенов, В.А.Статов

Қарақалпақ мемлекеттік университеті, Нукус, Өзбекстан

Аннотация.

Мақалада Оңтүстік Арал теңізі мен Солтүстік Каспийді пайдаланумен салыстырмалы ландшафтық зерттеулерді қолдау үшін жергілікті геоботаникалық мәліметтер базасы мен ғаламдық ақпараттық жүйелерді біріктіру туралы айтылады. Мақалада сонымен қатар антропогендік факторлар жағдайында ландшафттың өзгеруі, ГАЖ технологиялары мен қашықтықтан зондтау технологиялары қолданылады.

Integration of local geobotanical databases with global information systems to support comparative landscape science

N.K.Mamutov, P.R.Reymov, S. J. Abdireymov, Ya.G. Khudaybergenov, V.A.Statov

Karakalpak State University, Nukus, Uzbekistan

Annotation.

The article discusses the integration of local geobotanical databases and global information systems to support comparative landscape studies using the South Aral Sea and the North Caspian. The article also explores landscape changes under anthropogenic factors using GIS technology and remote sensing. 
Современный этап аномально быстрых глобальных антропогенных изменений природных экосистем вызывают обоснованную обеспокоенность сохранением естественных местообитаний и ландшафтов, самой принципиальной возможностью сохранения биоразнообразия и устойчивости экосистем. Сложившиеся методы геоботанических, биогеографических и ландшафтоведческих исследований обычно рассматривают на конкретные локальные природно-территориальные комплексы, исследуя их современное состояние, динамику, генезис геоэкологической системы, устойчивость и разнообразие. Переход к последующим уровням пространственной генерализации, к провинциям, климатическим поясам и другим крупным физико-географическим общностям происходит за счет усреднения и потери важных сущностных факторов, уменьшения размерности исследуемой системы.

Однако достигнутый в настоящее время масштаб сбора и обработки данных, преимущественно с использованием средств космического мониторинга, успехи в обработки данных большой размерности позволяют надеяться на преодоление этого методологического барьера в биогеографических исследованиях. Высокое разрешение и регулярных охват мультиспектральных космоснимков, доступность инфракрасной, радиометрической и радиолокационной съемки, возможность контроля физикогеографических процессов с помощью гравиметрического мониторинга, радиолокационный контроль процессов в почве и растительном покрове дают принципиальную возможность количественного сравнительного анализа различных регионов с почвенными и климатическими условиями. Такой подход, сохраняя физико-географическую детализацию всех составляющих природно-территориального комплекса, их внутренних взаимосвязей, сингенетических связей в ландшафтной системе, доступную для наземных экспедиционных исследований вместе с тем открывает принципиально новые возможности для географии трансформирующихся ландшафтов [1].

В качестве инструмента исследования используются средства геоинформатики и геостатистики, позволяющие создавать многомерные массивы пространственно привязанных параметров для поиска корреляций и сопоставления деталей ландшафтной структуры.

Важным инструментальным средством создания сравнительной ландшафтной модели являются семейства спектральных индексов (вегетационных, водных, пустошных, яркостно-солончаковых, сульфатных и других), которые будучи объединены с геомофологическими индексами позволяют непосредственно выявлять морфологическое подобие топографической структуры, функциональное подобие местообитаний, эколого-эдафическое подобие и климагенное различие экотопов, структурноморфогенетическое подобие экосистем, пространственные индексы ландшафтного разнообразия, а также геохимические аспекты состояния почвогрунтов и процессов почвообразования [2].

Однако для такой важной части сравнительно-геоэкологического исследования как определение многомерного фитоценотическое подобия растительных сообществ, необходимо средства сопоставления функциональных роли растений-эдификаторов и основных растительных сообществ, формирующих катены в сравниваемых местообитаниях, нужен дополнительный инструментарий для работы с геоботанической информацией, сопоставления функционально подобных, но различающихся по входящим в них видам растительных сообществ. Поэтому в настоящем исследовании мы предлагаем проводить объединение геоботанических баз данных [3] и операцию функционального сопоставления фитоценозов с помощью экологических шкал, в частности шкалы Л.Г.Раменского [4, 5, 6], как наиболее адаптированной к аридным экосистемам. При этом реляционный механизм связи с фитофизиологическими и фитоморфологическими базами (TRY [7]) позволяет поддерживать необходимый уровень достоверности при недостаточности информации об одном из сравниваемых местоообитаний.

В качестве примера сравнительного геоэкологического и геоботанического анализа нами рассмотрены генетически подобные ландшафты аридных дельт Северного Прикаспия (дельта реки Урал) и Южного Приаралья. Нами, как по литературным данным, так и с помощью интерпретации данных дистанционного зондирования, а также с помощью анализа цифровых моделей рельефа оценивалось подобие экосистем и анализировался текущий этап их трансформации. Было обнаружено значительное структурно-функциональное подобие опустыненной части дельты реки Урал и целому ряда экотопов современной дельты, частично сохраняющих гидрогенный режим. 
Нами показано, что в случаях катастрофически трансформирующихся природно-территориальных комплексов, к которым относятся многие внутриконтинентальные дельты аридной зоны, в том числе и низовья Амударьи, ограничения традиционных методов ландшафтоведческих могут быть преодолены не только мультимасштабным картографированием, имитационным моделированием ландшафтообразующих и геохимических процессов, режимом постоянного мониторинга ключевых участков природнотерриториального комплекса, расширенными методами классификации и интерпретации данных дистанционного зондирования, но также и сравнительно-ландшафтоведческими подходами с привлечением перекрестной геоботанической индикации $[8,9]$. Авторы выражают искреннюю признательность проекты Европейского Союза DSinGIS 585718-EPP-1-2017-1-HU-EPPKA2-CBHE-JP (2017-3069/001001) i EPCA 585382-EPP-1-2017-1-SE-EPPKA2-CBHE-JP sposobstvovavshiemu dannym issliedovaniiam.

\section{Litieratura}

1. Khudaibierghienov Ia.G. Gieoekologhichieskiie priedposylki sravnitiel'nykh landshaftoviedchieskikh issliedovanii na primierie Iuzhnogho Priaral'ia i Sieviernogho Prikaspiia //v sb. Matierialy Miezhdunarodnoi nauchno-praktichieskoi konfierientsii «Проблемы и перспективы комплексных географических исследований в Аральском регионе и сопредельных территориях.» Нукус, 15-16 мая 2018 года.

2. Monica G. Turner, Robert H. Gardner Quantitative Methods in Landscape Ecology: The Analysis and Interpretation of Landscape Heterogeneity. Springer New York, 1994. 536 pages.

3. Новикова Н.М., Кузьмина Ж.В., Трофимова Г.Ю., Дикарева Т.В. Обработка и анализ ботаникогеографической базы данных для оценки изменения растительности и почв//в сб. Биогеография, 1997, т.6, Изд. МЦГО Москва, с. 12-15.

4. Бузук Г.Н. Экологические шкалы Л. Г. Раменского: новые возможности// Разнообразие растительного мира, 1 (13), 2018, с. 37-43.

5. Жуков А. В. Фитоиндикационное оценивание измерений, полученных при многомерном шкалировании структуры растительного сообщества// Ukrainian Journal of Ecology, vol. 5, no. 1, 2015, pp. 69-93.

6. Breckle S-W., Wucherer W. Halophytes and salt desertification in the Aralkum Area// in :Aralkum - a Man-Made Desert: The Desiccated Floor of the Aral Sea (Central Asia) eds.S-W. Breckle, W. Wucherer, L.A. Dimeyeva, N.P. Ogar Springer Science \& Business Media, 2011 - 488 p. pp.271-300.

7. Kattge, J. et al. TRY - a global database of plant traits.//Global Change Biology, 2011, V. 17, pp.29052935.

8. Реймов П.Р., Мамутов Н.К., Статов В.А., Реймов М.П., Худайбергенов Я.Г., Абдиреймов С.ЖК. Мониторинг степени опустынивания дельт аридных регионов с помощью спектральных индексов//в сб."Материалы Международной научно-практической конференции "Геоэкологические проблемы аральского бассейна: научные идеи, исследования,инновации" (14-15 июнь, 2019, Ташкент). -Ташкент, 2019. - 382 с. с.156-157.

9. Бахиев А., Новикова Н.М., Куст Г.С., Мамутов Н., Трешкин С.Е., Гладышев А.И., Пак В., Кузьмина Ж.В., Аветян С.А., Дикарева Т.В., Капустин Г.А., Розов Ю.С. Результаты экологических исследований на Муйнакской международной станции в дельте Амударьи// Вестник Каракалпакского отделения АН Узбекистана, 1995, 2 (140). 